\title{
LOGISZTIKA SZEREPE A KÖRFORGÁSOS GAZDASÁGBAN
}

\author{
Szászi Barna \\ BSc hallgató, Miskolci Egyetem \\ Logisztikai Intézet \\ 3515 Miskolc, Miskolc-Egyetemváros, e-mail: szaszibarna@gmail.com \\ Bányainé Tóth Ágota \\ egyetemi docens, Miskolci Egyetem \\ Logisztikai Intézet \\ 3515 Miskolc, Miskolc-Egyetemváros, e-mail: altagota@uni-miskolc.hu
}

\begin{abstract}
Absztrakt:
A globális környezeti problémák a világ minden pontján érzékelhetök, függetlenül attól, hogy mely földrészen élünk. Európában évi 2,5 milliárd tonna hulladékot termelünk, ami jelentös mértékben hozzájárul a környezeti terhelés fokozódásához. Ezt felismerve az Európai Unió 2015-ben hozott döntésének értelmében a közösség stratégiai céljává emelte a körforgásos gazdaság megvalósitását. Jelen cikk keretében a szerzök bemutatják a körforgásos gazdaság jelentöségét valamint a logisztika szerepét a körforgásos gazdaság megvalósitásában.
\end{abstract}

Kulcsszavak: lineáris gazdaság, körforgásos gazdaság, logisztika, hulladékgazdálkodás

\section{Abstract:}

Environmental aspects of economy represent global problems in the world. Europe produces 2.5 billion tonnes of waste, which has a great impact on environmental sustainability. In 2015 the European Union decided to declare circular economy as one of the most important direction of its strategy. Within the frame of this article the authors describe the importance of circular economy focusing on the logistic aspects.

Keywords: linear economy, circular economy, logistics, waste management

\section{Bevezetés}

A globális környezeti problémák a világ minden pontján érzékelhetők, hiszen mindannyian átéljük az időjárási anomáliákat, megtapasztaljuk a szennyező anyagok szervezetünkben való felhalmozódásából származó egészségügyi problémákat és érzékeljük a nyersanyagok fogyásából eredő alapanyag áremelkedéseket. Ezt felismerve, a 2012-ben megrendezett Rio+20 ENSZ konferencián született döntés alapján, 2015-ben került sor a Fenntartható Fejlődési Keretrendszer elfogadására [1].

Ennek hatására az Európai Unió 2015-ben a közösség stratégiai céljává emelte a körforgásos gazdaság megvalósítását, melynek értelmében az Unió korszerúsíti a hulladékkezelésre vonatkozó jogszabályait, így ösztönözve a lineáris gazdaságról való átállást a körforgásos gazdaságra.

Jelen kutatás célja annak feltárása, hogy a lineáris gazdasági szemlélet milyen pazarló túlfogyasztáshoz és környezetszennyezéshez vezetett. Röviden bemutatjuk a körforgásos gazdaság termelési modelljét, összehasonlítva a lineáris gazdasági modellel. Külön kitérünk arra, hogy milyen 
jelentőséggel bír a logisztika a körforgásos gazdaság megvalósításában. Néhány ,jó gyakorlat” bemutatásával a körforgásos gazdaság megvalósítása során jelentkező problémák megoldására mutatunk alternatívákat.

\section{Lineáris gazdaság}

A gazdaságilag fejlettnek tekinthető országok napjainkban jellemzően a lineáris gazdasági modell szerint müködnek, ami a folytonosan növekvő termelési igényekre és a korlátlanul rendelkezésre álló olcsó energiaforrások meglétére támaszkodik. Ebben a rendszerben a nyersanyagok kitermelése után az alapanyagokból készterméket állítanak elő, amit a fogyasztó megvásárol, majd a használatot követően eldob. A Föld természetes erőforrásai és nyersanyagai a túlfogyasztás miatt lassan kimerülnek. A jelenlegi állapotban, ha nem történik semmiféle változás, a népesség növekedése és a gazdaság széleskörü bővülése, a nyersanyagkészletek fogyása, a kitermelési költségek további emelkedése fenntartja a magas nyersanyagárakat és az áringadozás lehetőségét a jövőben is. Európában a helyzetet tovább súlyosbítja, hogy importból származik a nyersanyagok $40 \%$-a, és ez a szám a stratégiai erőforrások esetében még magasabb [2].

Elemzések szerint 2030-ra a világban kb. 3 milliárd új fogyasztó jelenik majd meg. A termelés jelenlegi szerkezete ezeket az igényeket és ezt a mennyiségü fogyasztást már egészen biztos, hogy nem lesz képes kielégíteni és a jelenlegi színvonalon elöállítani. A gyártási folyamatokban ugyan vannak még a hatékonyságnövelésre vonatkozóan tartalékok, de ezek a tartalékok már nem elegendőek valódi versenyképes piac biztosításához.

A jövőben a mezőgazdasági tevékenységek is lassabban fognak növekedni, amely problémát tovább fokoz a talajminőség folyamatos romlása, ami az élelmiszeripar minőségbiztonsági kockázatát fokozza. A helyzetet tovább súlyosbítja, hogy a világon körülbelül 1,3 milliárd tonna élelmiszer kerül kidobásra. Az EU-ban évente 88 millió tonna, egy före vetítve $173 \mathrm{~kg}$ élelmiszert dobnak ki (1. ábra).

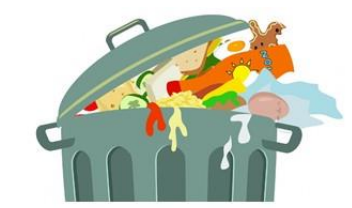

világon 1,3 milliárd tonna

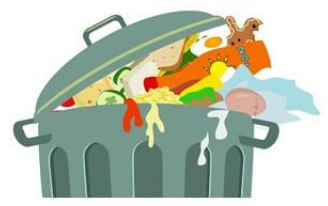

EU-ban 88 millió tonna

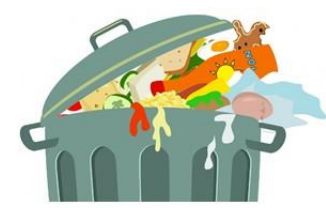

egy ember $173 \mathrm{~kg}$

\section{1. ábra Az élelmiszerhulladék évi mennyisége [3]}

A lineáris gazdaságra jellemző, hogy a termék életciklusa során a kitermelés-gyártás-kereskedelemelosztás folyamaton át a fogyasztóhoz eljuttatott terméket a használati idő eltelte után hulladékként kezeli. Ezáltal a termékekbe fektetett munka, energia és anyag a gazdaság számára elvész, ami a természeti erőforrásokat pazarló, a világot hulladékkal elborító fogyasztói társadalom létrejöttét eredményezte.

A fentiek alapján kijelenthetjük, hogy a lineáris gazdaság hosszútávon nyersanyagellátási és környezetvédelmi problémákat indukál, melyek egyértelmüen befolyásolják és határt szabnak ennek a gazdasági müködésnek. Ezen felismerések alapján, a jelentkező problémák megoldására napjainkban már több gazdaságfejlesztési koncepciót dolgoztak ki, melyek közül a tanulmányban a körforgásos gazdaság nyújtotta lehetőségeket kívánjuk bemutatni. 


\section{Körforgásos gazdaság jellemzői}

A körforgásos gazdaság célja a használatban lévő termékek, anyagok és erőforrások értékének a lehető leghosszabb ideig történő megóvása és fenntartása, továbbá a hulladékkeletkezés minimalizálása, beleértve a hulladékhierarchia alkalmazását [4].

Az elmélet szerint a körforgásos gazdaságban a természeti körforgás sémáját kell alkalmazni: ahogyan az anyagok a napenergia segítségével az élettelen és élő környezeti tényezők között zárt körfolyamatokban áramlanak, ezt az áramlást kell átemelni a gazdasági folyamatokra. Ennek analógiájára a gazdasági folyamatokban résztvevő anyagokat is ameddig erre lehetőség van, folyamatosan zárt körfolyamatokban kell áramoltatni a gazdasági szereplök között.

A 2. ábra a körforgásos gazdaságra jellemző termék életciklust mutatja be, ahol a termék előállítása mellett az egyik legfontosabb feladat a termelési-gazdasági folyamatok során az anyagba, termékbe fektetett munka és energia megőrzése.

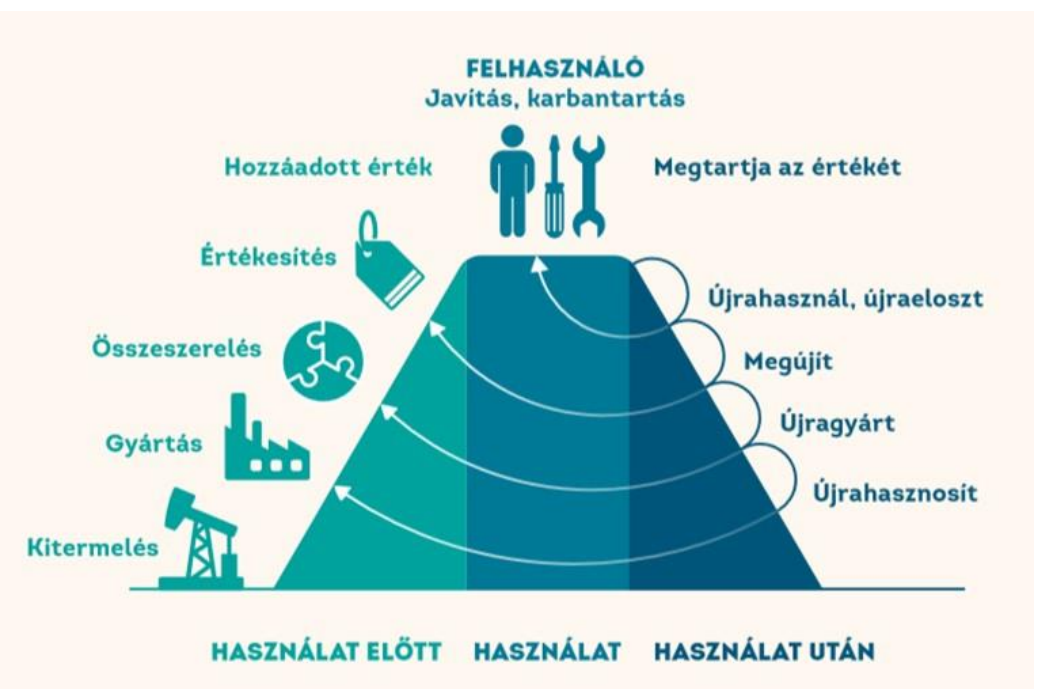

2. ábra Értékpiramis a körforgásos gazdaságban [2]

Ennek érdekében a gazdaság szereplöinek bevonásával értékmegőrző, értékfelújító, újrafeldolgozó rendszereket hoz létre és müködtet, hogy meghosszabbítsa azt az időt, amit a termék a gazdasági folyamatokban eltölt.

Ezek alapján a körforgásos gazdaság jellemzői a következők [2]:

- az erőforrásgazdálkodásban a hangsúlyt az erőforráshatékonyságra helyezi, továbbá új üzleti modellek bevezetésével csökkenti az erőforrásigényt,

- tudatos tervezéssel meghatározza, beazonosítja és megszünteti a folyamatokban a hulladékokat,

- csökkenti az elsődleges nyersanyagok felhasználását,

- megszünteti az egészségre, a környezetre veszélyt jelentő anyagok felhasználását, mivel ezen anyagok visszaforgatására nincs lehetőség,

- támogatja a környezettudatos tervezést, javítást és karbantartást,

- a felhasználótípusú fogyasztói magatartásra helyezi a hangsúlyt, melynek lényege, hogy a tulajdon mindvégig a gyártónál marad, a felhasználó csak bizonyos szolgáltatásokat vesz igénybe, 
- a termékfelelősség kiterjesztésével megteremti a gyártók és forgalmazók érdekeltségét,

- a gyártó felelössége az elhasználódás után is fennmarad, így érdekeltté válik a megnövelt életciklusú termékek elöállításában.

A körforgásos gazdaság müködési modelljét a 3. ábra szemlélteti. A körforgásos gazdaságban ideális esetben a keletkezö hulladék közel teljes mennyisége hasznosul, másodlagos nyersanyagként visszakerül az ipari termelésbe, és elsődleges nyersanyagok csak akkor kerülnek felhasználásra, ha másodlagos nyersanyagok nem állnak rendelkezésre.

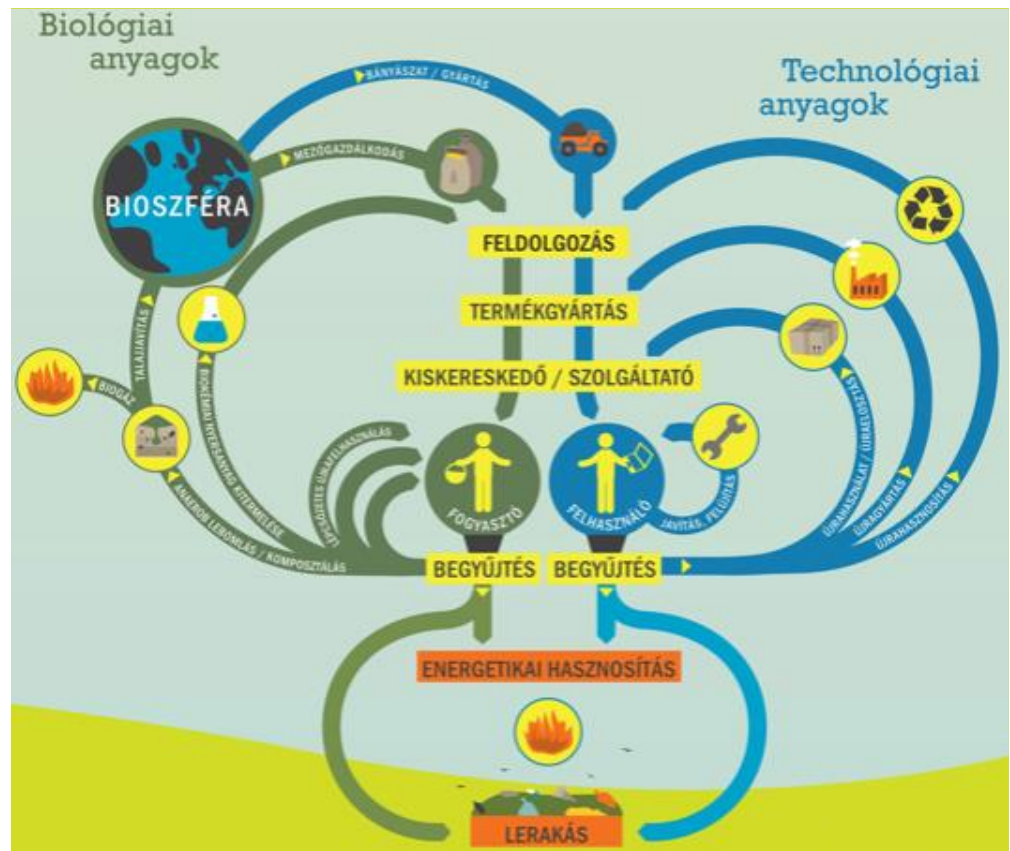

3. ábra A körforgásos gazdaság müködési modellje [5]

A körforgásos gazdaság megvalósítása érdekében az EU cselekvési tervének megfelelően a tagállamok új szabályokat, gazdasági eszközöket, intézkedéseket vezetnek be, melyek révén a gyártói felelősségi rendszerek kiterjesztésével elősegítik a környezettudatos tervezést, karbantartást, javítást, jótállási idők kitolódását, a termékek tartós használatának megvalósítását. A gyártói felelősségi rendszerek kiterjesztése tekintetében az első mérföldkő szerint valamennyi csomagolás vonatkozásában létre kell hozni a kötelező, kiterjesztett gyártói felelősségi rendszereket 2024-ig [6].

\section{Logisztika a körforgásos gazdaságban}

A körforgásos gazdaság megvalósításában jelentős feladatok hárulnak a logisztikára. Az újrahasznosítási folyamatok költségének kb. 70\%-át a logisztikai költségek teszik ki, ezért az alkalmazott logisztikai rendszerek jelentősen befolyásolják a müködés hatékonyságát.

A háztartási eszközök, elektronikai berendezések újrahasznosítási láncának megszervezését a technológiai fejlődésből adódó felgyorsult elévülés, az emiatt keletkező nagy termékmennyiség és a használt termékek feldolgozásából elérhető haszon motiválja elsősorban, de nem hanyagolható el a 
környezetmegóvás miatti motiváció sem. Az újrahasznosítás folyamata során a felhasználó az elhasznált terméket valamilyen begyüjtési rendszer segítségével eljuttatja az újrahasznosítást végző gazdasági szereplöhöz. Az újrahasznosítás során az elhasznált termék szétszerelését követően a már tovább nem hasznosítható anyagot deponálóban helyezik el. A tovább hasznosítható anyagok egyik csoportja a feldolgozás után vagy a szervízhálózathoz kerül, vagy pedig mint újrahasznosítható alapanyag visszakerül a gyártásba. A másik csoportot az energiatermelésben használják fel energia kinyerésére.

Az újrahasznosítási folyamatok logisztikai részfolyamatai: az elhasznált termékek gyüjtési folyamata, a szétszerelési folyamat, a szelektálási folyamat, az elosztási folyamat és a hulladék logisztikai folyamat. A logisztikai folyamatok megvalósítását végző logisztikai alrendszerek feladatai [7]:

- Az elhasznált termékek gyüjtési logisztikájának feladata, hogy az elhasznált berendezés a felhasználótól eljusson a szétszerelö helyre. Fő feladata a begyüjtés megszervezése, ami magában foglalja a felhasználótól a szétszerelőhelyig terjedő anyagáramlás és az ehhez kapcsolódó információáramlás megtervezését, megszervezését, irányítását és ellenőrzését.

- Az elö- és szétszerelés logisztikája a bemenő tárolótól a szétszerelési folyamat különböző fázisain át a kimenő tárolóig terjedő anyagáramlást tervezi, szervezi, irányítja és ellenőrzi. Főbb feladatai közé tartozik a be- és kilépő tárolás, rakodás, egységrakomány-bontás, műveletközi szállítás.

- A szelektálási logisztika a szétszerelt elemek osztályozásával, tárolásával, egységrakomány képzésével és a feldolgozó helyre való szállításával foglalkozik.

- Az újrafeldolgozási logisztika megtervezi, megszervezi, irányítja és ellenőrzi az anyagáramlást az újrafeldolgozás különböző fázisain át. Fő feladatai közé tartozik a szétszerelt elemek rakodása, tárolása, a feldolgozási folyamat műveletei közötti szállítás, tárolás és rakodás, valamint a feldolgozott elemek egységrakomány képzése.

- Az elosztási logisztika feladata, hogy a feldolgozást követően az újrahasznosítható anyagok az előkészítő helyről eljussanak az új terméket elő́llító céghez. Feladata a kimenő tárolótól a felhasználóig terjedő anyagáramlás és a hozzá tartozó információáramlás tervezése, szervezése, irányítása és ellenőrzése.

- A hulladék logisztika feladata a már nem hasznosítható anyagok anyagáramlásának megtervezése, megszervezése, irányítása és ellenőrzése. Ide tartozik a hulladékok szállítása, osztályozása, deponálása és megsemmisítése.

A gyüjtési logisztikai rendszer tervezésénél alapvető feltétel a többfokozatú gyüjtés, ahol az egyes fokozatok: gyüjtőállomás, vásárlói központ, gyüjtőhely, gyüjtési központ. A fogyasztótól az elhasznált berendezés kétféle módon juthat el a gyüjtőállomásra: az egyik lehetőség, hogy a fogyasztó végzi a beszállítást kereskedelmi csereakció keretében; a másik lehetőség, hogy a gyüjtóállomás szervez gyüjtőjáratokat az elhasznált berendezések begyüjtésére. A gyüjtőállomások feladata a begyüjtés és a tárolás.

A gyüjtési rendszer következő fokozata a vásárlói központ, ahova a gyüjtóállomásokról gyüjtőjáratok szervezésével jutnak el az elhasznált berendezések. A vásárlói központokban a gyüjtőállomásokhoz hasonlóan a begyüjtés és a tárolás az alapvető feladat. A vásárlói központokból az elhasznált berendezéseket a gyüjtőhelyekre szállítják a vásárlói központ által szervezett gyüjtőjáratokkal vagy visszáru keretében. A gyüjtési rendszer utolsó fokozata a gyüjtőközpont, ahova a gyüjtőhelyek szállítják be az elhasznált berendezéseket a gyüjtőhely által szervezett gyüjtőjáratokkal vagy visszáru keretében [8]. A gyüjtési logisztikai rendszer optimális kialakítása jelentősen befolyásolja a rendszer müködtetési költségét, így alapvető cél a megfelelő számú gyüjtési fokozat meghatározása. 


\section{5. „Jó gyakorlatok” a nagyvilágban}

Az olajipar után a második legszennyezőbb iparág a textilipar, amely a világ $\mathrm{CO}_{2}$ kibocsátásának tizedéért felel. A jelentős környezeti terhelés következtében egyre nagyobb a nyomás a gyártókon, akik számos körforgásos gazdasági eszközöket alkalmazó innovatív megoldást dolgoztak ki és alkalmaznak. Így lett a textilipar a körforgásos gazdaság úttöröje. Ilyen innovatív megoldásnak számít a Nike kezdeményezése, melynek keretében használt sportcipőket gyüjtenek össze világszerte. Az összegyüjtött cipőket ledarálják, az így keletkező darabokból pedig sportálya-felületet állítanak elő. A program kezdete óta 28 millió pár cipőt gyüjtöttek össze és hasznosítottak újra sportpálya formájában. Hasonlóan innovatív megoldást dolgozott ki a svéd H\&M. 2013-ban indították „Bring it” kampányukat, melynek keretében a vásárlók által bevitt használt ruhákat visszakapcsolják a körforgásba: a jó minőségüeket tovább adományozzák, a többit vagy újrahasználatra adják tovább vagy újrahasznosítják és fonal lesz belőle. Eddig 40000 tonna ruhát mentettek meg globálisan [9].

Az elmúlt években megfigyelhető tendencia, hogy fokozódik az elektronikai termékek iránti kereslet. Az emberek például átlagosan 2,5 évente cserélik le okostelefonjukat. Ez a keresletnövekedés együtt jár az elektronikai hulladékok felhalmozódásával. Ezt a jelenséget kihasználva, a környezet és/vagy költségtudatos fogyasztókat megcélozva néhány vállalat, közöttük magyar cégek is, felújított okostelefonokat és egyéb elektronikai eszközöket kínálnak, egy éves garanciával, az eredeti árnál lényegesen olcsóbban.

Jelenleg a körforgásos gazdaságra való átállás csak egy lehetőség - lehetőség az innovációra, értékteremtésre és új fogyasztók elérésére. Ezzel egy időben, világszerte számos kormány tesz erőfeszítéseket a körforgásos gazdaságra való átállás elősegítésére, mind támogatások, mind szabályozások formájában.

\section{Köszönetnyilvánítás}

A cikkben ismertetett kutató munka az EFOP-3.6.1-16-2016-00011 jelü „Fiatalodó és Megújuló Egyetem - Innovatív Tudásváros - a Miskolci Egyetem intelligens szakosodást szolgáló intézményi fejlesztése" projekt részeként - a Széchenyi 2020 keretében - az Európai Unió támogatásával, az Európai Szociális Alap társfinanszírozásával valósul meg.

\section{Felhasznált irodalom}

[1] https://ensz.kormany.hu/a-2030-fenntarthato-fejlodesi-keretrendszer-agenda-2030-

[2] http://www.hermanottointezet.hu/sites/default/files/hozd\%20magad\%20korforgasba_teljes.pdf

[3] http://www.europarl.europa.eu/sides/getDoc.do?pubRef=-//EP//TEXT+REPORT+A8-20170175+0+DOC+XML+V0//HU\#_part1_def17

[4] Az Európai Parlament és a Tanács rendelete. Forrás: https://eur-lex.europa.eu/legal-content/HU/ TXT/?qid=1542355914535\&uri=CELEX:52018PC0353

[5] www.hulladek.eu

[6] http://europa.eu/rapid/press-release_IP-18-3846_hu.htm

[7] Cselényi J. (szerk.): Logisztikai menedzsment I.-II. TDQM Phare, Miskolc, 1997.

[8] Cselényi J., Illés B.: Logisztikai rendszerek I., Miskolci Egyetem, 2004.

[9] https://www.pwc.com/hu/hu/kiadvanyok/assets/pdf/korforgasos.pdf 